\title{
On the Guardianship Function and System Construction of Civil Affairs Departments Based on the General Principles of the Civil Law \\ Chunxue Fan
}

Bei Hua University, No. 3999 East Binjiang Road, Jilin, Jilin, China

418470072@qq.com

\begin{abstract}
Keywords: General Principles of the Civil Law of the People's Republic of China; Guardianship of a minor; Guardianship of an adult; Civil affairs departments
\end{abstract}

\begin{abstract}
After the publication of the General Principles of the Civil Law of the People's Republic of China (General Principles of the Civil Law), The rights and obligations of the civil affairs departments in carrying out the duties of the guardians or supervising the guardians should be implemented and the norms should be refined so that the law will not become a dead letter. This paper mainly demonstrates by a method of literature research and case analysis. Articles on the guardianship function of civil affairs departments are mainly published in recent three years, and there were very few disputes cases with civil affairs departments involved. Legislation has attached importance, but the legal principle researches and judicial practices are still not enough.
\end{abstract}

\section{Introduction}

The General Principles of the Civil Law of the People's Republic of China was approved in the Fifth Session of the Twelfth National People's Congress of the People's Republic of China on March 15, 2017, and the President of the People's Republic of China Xi Jinping signed the Presidential Decree No. 66. The General Principles of the Civil Law shall come into force from October 1, 2017. The publication of this law is significant for the establishment of legal system to adjust the civil legal relationship in PRC. It draws a satisfactory conclusion for the enactment of civil law discussed in jurisprudential circle for many years, and determines the basic principles and legislative keynote of subchapters at the next stage. In the process of learning this law, the author had a strong interest in the role of guardianship system that highlights the civil affairs departments, and thus conducted an intensive study.

\section{Meaning of Civil Affairs and Functions of Civil Affairs Department}

Meaning of Civil Affairs. Civil affairs, the administrative department in charge of civil affairs or the administrative affairs related to people managed by the government, such as marriage registration, disaster relief, preferential treatment, supporting government and cherishing people, zoning of administrative areas, aging work, subsistence allowances, welfare, charity, funeral and rescue and other social affairs.

Functions of Civil Affairs Department. In China's current organizational structure, the civil affairs departments are established with the national Ministry of Civil Affairs, with Civil Affairs Department in different provinces, with Civil Affairs Bureaus in cities and counties and with Social Affairs Offices in villages and towns.

The official website of the Ministry of Civil Affairs presents 12 main responsibilities of civil affairs departments. Literally it does not mention the implementation of the duties of a particular natural person in these 12 functions, but in the Article 8 and Article 9 there're guidance about the protection of the rights and interests of special groups such as the elderly, orphans and the disabled, and guidance about the management of help service agencies. In addition, there is no department specialized in carrying out the guardianship functions of a specific natural person from the establishment of departments of the Ministry of Civil Affairs. It can be seen that, before the publication of the General Principles of Civil Law, the setting of civil affairs departments did not match the provisions of civil affairs departments indicated in the General Provisions of the Civil 
Law, and naturally the departments could not implement the civil legal acts involved in the General Provisions. It can be said that the relevant provisions on rights and obligations of civil affairs departments in the General Provisions of the Civil Law are unenforceable for more than 30 years since 1986.

\section{Comparison between the General Principles of Civil Law and the General Provisions of the Civil Law on the Guardianship of Civil Affairs Departments}

From the number of articles, number of appearances, functions and the relationship between civil affairs departments and other guardianship subjects, etc., The General Principles of Civil Law attaches greater importance on the guardianship responsibility of civil affairs departments.

Table 1 Comparison of legal provisions

\begin{tabular}{|c|c|c|c|c|}
\hline & Articles & $\begin{array}{l}\text { Numb } \\
\text { er of } \\
\text { Appea } \\
\text { rances }\end{array}$ & Functions & $\begin{array}{l}\text { Relationship with } \\
\text { Neighborhood/Vil } \\
\text { lage Committee }\end{array}$ \\
\hline $\begin{array}{l}\text { General } \\
\text { Provisions } \\
\text { of the } \\
\text { Civil Law }\end{array}$ & 16,17 & 2 & Act as guardian & Parallel \\
\hline $\begin{array}{l}\text { General } \\
\text { Principles } \\
\text { of Civil } \\
\text { Law }\end{array}$ & $\begin{array}{l}24, \quad 27, \\
28, \quad 31, \\
32,36\end{array}$ & 10 & $\begin{array}{l}\text { 1. Apply for identification or restore of the } \\
\text { person having no capacity for civil conduct } \\
\text { or person with limited capacity for civil } \\
\text { conduct to the court } \\
\text { 2. Approval of other individuals or } \\
\text { organizations willing to act as guardians } \\
\text { 3. Designated guardians } \\
\text { 4. As an interim guardian } \\
\text { 5. As a guardian } \\
\text { 6. Revoking of guardian qualification }\end{array}$ & $\begin{array}{l}\text { Priority in } \\
\text { sequential order } \\
\text { and functional } \\
\text { scope expanded }\end{array}$ \\
\hline
\end{tabular}

From the above table we can see that the General Principles of Civil Law gives the civil affairs departments more rights and obligations. Articles 24, 27, 28, 31, 32 and 36 are related to civil affairs departments, and except section one of article 24, the others are under the custody of the second section. We can see that the performance of the civil affairs departments is mainly about the performance of rights and obligations related to guardianship.

\section{The Rights and Obligations of the Civil Affairs Departments}

Apply to Identify (Restore) the Adult's Ability to Act. Article 24 For an adult incapable of discerning or fully discerning his or her conduct, an interested party or a relevant organization may apply to a people's court for determining the adult as a person without capacity for civil conduct or a person with limited capacity for civil conduct.

After the adult is determined by a people's court as a person without capacity for civil conduct or a person with limited capacity for civil conduct, the people's court may, based on the recovery of his or her intelligence or mental health, determine the adult as a person with limited capacity for civil conduct or a person with full capacity for civil conduct, upon his or her application or application of an interested party or a relevant organization.

For the purposes of this article, the relevant organizations include but are not limited to: an urban residents' committee, a villagers' committee, a school, a medical institution, a women's federation, a disabled persons' federation, an organization legally formed for seniors, and a civil affairs department, among others. 
Agree Other Persons or Organizations who are willing to Act as Guardians as Guardians. Article 27 the parents of a minor are his or her guardians.

Where both parents of a minor are dead or incapable of acting as a guardian, one of the following persons capable of acting as a guardian shall act as the guardian of the minor in the following order:(1) Paternal or maternal grandparents of the minor.(2) Elder brothers or sisters of the minor.(3) Other individuals or organizations willing to act as the guardian, provided that it is approved by the urban residents' committee, villagers' committee, or civil affairs department of the place of the minor's domicile.

Article 28 One of the following persons capable of acting as a guardian shall, in the following order, act as the guardian of an adult without capacity for civil conduct or with limited capacity for civil conduct:(1) Spouse of the adult.(2) Parents or children of the adult.(3) Other close relatives of the adult.(4) Other individuals or organizations willing to act as the guardian, provided that it is approved by the urban residents' committee, villagers' committee, or civil affairs department of the place of the adult's domicile.

Designated Guardians. Article 31 In case of any dispute over the determination of guardian, the urban residents' committee, villagers' committee, or civil affairs department of the place of the ward's domicile may designate the guardian, and against the aforesaid designation, the relevant parties may apply to the people's court for designating the guardian; and the relevant parties may, notwithstanding, directly apply to the people's court for designating the guardian.

The urban residents' committee, villagers' committee, civil affairs department, or people's court shall respect the true will of the ward, and designate the guardian from among persons legally qualified for guardianship under the principle of most benefiting the ward.

(Temporarily) Act as Guardian. Article 31 Before the guardian is designated under paragraph 1 of this article, if the personal rights, property rights, and other lawful rights and interests of the ward are under no protection, the urban residents' committee, villagers' committee, relevant organization prescribed by the law, or civil affairs department of the place of the ward's domicile shall act as the provisional guardian.

Article 32 Where there is no person legally qualified for guardianship, the civil affairs department may or the urban residents' committee or villagers' committee of the place of the ward's domicile satisfying the conditions for performing the duty of guardianship may act as the guardian.

Comparing with the final version, the change of second version (In terms of person without guardianship qualification, the residents' committee, the village committee or the civil affairs department shall act as the guardian) is to determine the priority of the civil affairs department in sequential order, which attaches greater importance on the role of civil affairs departments in guardianship.

This provision is important for the elderly. In recent years, with the arrival of "silver hair tide", there are more and more empty-nest elderly and elderly of no family. Although the elderly with five guarantees are supported by the civil affairs department, but there are some elderly without children or single elderly people without care of family members. [1] According to the provisions of Article 32 , the above problems can be solved, and the elderly people can be guarded by the civil affairs department.

Apply for Revoking of Guardian Qualification. Article 36 Where a guardian falls under any of the following circumstances, the people's court shall, upon application of the relevant individual or organization, disqualify the guardian, arrange necessary provisional guardianship measures, and designate another guardian in accordance with the law under the principle of most benefiting the ward:(1) Acting seriously to the detriment of the ward's physical and mental health. (2) Being slack in performing the duty of guardianship, or being incapable of performing the duty of guardianship but refusing to delegate part or all of the duty of guardianship to another person, which causes distress of the ward.(3) Otherwise seriously infringing upon the ward's lawful rights and interests.

For the purposes of this article, the relevant individuals and organizations include but are not limited to: any other person legally qualified for guardianship, an urban residents' committee, a villagers' committee, a school, a medical institution, a women's federation, a disabled persons' 
federation, an organization for the protection of minors, an organizations legally formed for seniors, and a civil affairs department.

Where the individuals and organizations except the civil affairs department as prescribed in the preceding paragraph fail to apply for the disqualification of the guardian to the people's court in a timely manner, the civil affairs department shall file such an application with the people's court.

Comparing with the General Provisions of the Civil Law, it is not only the right but also the responsibility to apply for the revocation of guardianship. This article has a connection with Article 32. The civil affairs department has the right to start (must start) the relevant legal procedures, and shall have the conditions for the subsequent placement of children (established with social welfare agencies). The civil affairs department is the natural representative of the country to fulfill the main responsibilities of guardianship.

\section{The Construction of Guardianship System in Civil Affairs Departments}

Necessity of Construction. On February 7, 2015, the first case to apply by civil affairs department for the revocation of guardian qualification pronounced judgment. It was reported that it was the first case by the civil affairs department to revoke the guardian qualification, and the first case in the whole country that applies to the Opinions on Several Issues Concerning the Treatment of Minors' Rights and Interests in Accordance with Law (the Opinions) that jointly promulgated by the Supreme People's Court, the Supreme People's Procuratorate, the Ministry of Public Security and the Ministry of Civil Affairs and implemented on January 1st this year.

The reason why the above case was called the "first case to withdraw the custody rights" is that the body applying for withdrawing is not specified, although the General Provisions of the Civil Law stipulates that the guardian qualification can be withdrawn. When the legal rights and interests of the guardian are seriously violated and no "relevant personnel or relevant entity" take the initiative to apply, the General Provisions of the Civil Law does not require mandatory application. Since the Opinions issued at the end of 2014, a national guardianship system with the civil affairs departments as the main implementation body is gradually formed. A work pattern with the minors rescue protection agencies to guard children who may be in danger and with child welfare institutions to support and attend the careless children is basically formed, but it still can not meet the real needs. [2] Therefore, the provisions of the General Principles of Civil Law on the civil affairs departments enhance the influence of the Opinions, and further implement a number of responsibilities for the civil affairs departments. Especially on the revocation of the qualifications of the guardian, the words used in the Opinions are "has the right". However, in clause 3 of Article 36 in General Principles of Civil Law, it is clearly stipulated that if any entity except the relevant individuals and civil affairs departments does not promptly apply to the people's court to revoke the guardian qualifications, the civil affairs department "should" apply to the people's court. This change is an alteration from the right to the obligation. We can see the General Principles of Civil Law places great hope on the civil affairs departments to protect the legitimate rights and interests of a particular natural person.

Issues Need Detailed Normalization in the Construction. Article 1 of the General Principles of Civil Law points out that "in order to protect the legitimate rights and interests of civil subjects, to adjust civil relations, to safeguard social and economic order, to adapt to the development of socialism with Chinese characteristics and propagate the socialist core values, this law is formulated based on the Constitution." This is the legislative purpose of the General Principles of Civil Law. "The life of the Constitution lies in the implementation, the authority of the Constitution also lies in the implementation". [3] Similarly, since the General Principles of Civil Law is based on the Constitution, the life and authority of the General Principles of Civil Law should also lie in the implementation. In terms of the functions of civil affairs departments under the guardianship system, if the functions cannot be implemented or effectively implemented, it not only deviates from the important mission assigned by legislators, but also makes the law become a dead letter. Taking the revocation of the custody of qualifications as an example, "At current stage of our country, the strength of public power intervention is limited, the level and effectiveness of exercise of rights 
urgently need to be improved. The deprivation of parental custody makes minors out of the family, which may cause a great shadow for the growth of minors." [4] Therefore, the author believes that the implementation of the General Principles of Civil Law must be accompanied by the corresponding rules to complete the system without detailed requirements in the General Principles, which means attention should be paid to the following issues in the system construction.

Civil affairs departments should set up a channel to ensure that a timely understanding of occurrence of cases that a specific natural person needs custody or his or her guardian qualifications should be revoked and then force the civil affairs departments to take the initiative to take responsibilities of custody.

The reason why the author has to think of this issue is that if comparing the civil affairs department with the company, the company has the motive to do various acts for their own interests. The characteristics for a commercial company "play roles together", which make the company has a unique attraction in terms of organization of effective activities. [5] However, the civil affairs departments carry more functions, and the existing mechanism is not very good for civil affairs departments to make full use of the resources in hands, which make these departments lack of internal motivation on active implementation of the custody responsibility. However, the failure to solve this problem or the lack of administrative responsibility norms may probably make civil affairs departments abstain from an act in practice. For example, some people think that the "first case to withdraw the custody rights" is not entirely "the victory of the system" and the occasional factor also played a significant role. The factor is the accidental discover of victim girl by a passer Zhang. That is to say if there is no chance encounter or compassion after the chance encounter, the girl may still face untold suffering. Moreover, from the articles written by personnel handling the case in the procuratorial authority that conducts prosecution of the victim's father, it's found that the application was not actively proposed by the civil affairs bureau in the beginning. The civil affairs bureau finally agreed to act as a application body only after several times of mobilization and detailed interpretation of the Opinions was given by the procuratorial authority. [6]

In this regard, the current mature approaches in US can give us inspiration. In 1963, the United States Children's Bureau developed a law of reporting. In 1974, the United States passed the Child Abuse Prevention and Treatment Act, requiring states to establish a mandatory reporting system. Today, in the United States, reporting range is very broad, e.g. children do not get the necessary care and supervision or children experienced serious emotional problems. The law also has the appropriate punishment for those who fail to report the facts. Once the biological parent or guardian is convicted of child abuse or unfavorable behavior for the child, the child will be taken away by the government and assigned to the government-designated adoptive family.

"The United States is made up of states that retain independent power, and China has had a central government that has controlled different provinces for thousands of years." [7] Comparatively speaking, since the states with independent powers have established a mandatory reporting system, we can see the degree of their attention to child custody. Thus, in a country where the local governments are controlled by the central government, a unified and more efficient monitoring mechanism should be developed. I believe that we can make use of the first power of neighborhood and village committees to establish a linkage mechanism same with the reporting function with the civil affairs departments, and a reporting mechanism for the relevant individual or entity, so that civil affairs departments can understand the specific needs of custody for a natural person as soon as possible. The former is easy to grasp the first-hand situation and make a preliminary judgment on whether there is no guardian or guardian's custody should be withdrawn, and then report to the civil affairs department. After the civil affairs departments know the relevant circumstances, investigation must be started to collect relevant evidence, which means to receive the case to further determine whether a guardian is required or a guardian's custody should be withdrawn.

The civil affairs department shall act as guardian and shall formulate the corresponding accountability mechanism in the case of failure to act as a guardian, or failure to apply for the revocation of the guardian's qualification when application is necessary. 
"Establishing a revocation of custody in the system can promote the original guardian's reflection of their behavior and responsibility and meanwhile protect the legitimate rights and interests of the guardian." [8] Therefore, only when the civil affairs departments effectively perform the guardianship functions well, the original guardians can reflect on their own behavior, or the guardianship system can not be improved. The existing legal norms only stipulate the civil affairs departments having the right to do or the way of doing only from the positive aspect, but did not stipulate the legal consequences of failure of doing, which may lead to the departments failure to perform their duties, or escape the responsibility as a guardian.

In the case that a civil affairs department should act as but didn't take the initiative to act as a guardian, the relevant legislation should give right to the relevant individual or organization to apply to the court to finally determine who should act as guardian by comparing the conditions of civil affairs departments and neighborhood (village) committees according to the provisions of Article 32 of the General Principles of Civil Law. If the civil affairs department was aware of the circumstances that should be withdrawn but failed to apply for the revocation of the guardian in accordance with the law, the relevant individual or organization may reflect to the higher-level administrative department of the civil affairs department or file an administrative omission to the court to improve the corresponding responsibility of civil affairs departments and the responsible person.

For the situation of performance of duties that the civil affairs department serves as a guardian, scientific and reasonable supervision and evaluation mechanism should be established. The civil affairs department has assumed a lot of responsibilities in the general rules by virtue of its follow-up conditions of guardianship. If the department does not provide the guardian with a good living environment or even infringes the legal rights and interests of the guardian, there's no supervisory mechanism stipulated in the General Principles of Civil Law. The author suggests that the supervisory mechanism of the higher authorities and the third party supervision and evaluation mechanism should be established, but the question is whether the scope of third party is limited and how to set a scientific and reasonable evaluation criteria, etc., which need to be improved by cases and experience gradually accumulated in practice.

It is workable to establish the prosecution of public interest litigation system acting as the useful supplement for civil affairs departments to fulfill the duties of guardianship. As mentioned above, the first case to withdraw the custody rights is a case settled under the guiding of prosecution authority. Some scholars are taking the opportunity to focus on whether it is workable to protect the legitimate rights and interests of minors by constructing a juvenile prosecution public interest litigation system, which is especially of great significance to the initiation of the proceedings and play a supervisory and warning role in the performance of the duties of the civil affairs departments. "The construction of a perfect juvenile public interest litigation system and custody withdrawing system is directly related to the stability of family and social relations and is the protection of personal rights and property rights of minors." [9]

\section{Conclusion}

Guardianship-related affairs are very complicated. Not only financial support, but also more care and patience are needed for looking after minors; in addition to take care of the daily life of minors, correct ideological guidance and teaching are necessary. The capacity of discovering problems from the daily contact with minors and correcting in a timely manner is also needed. [10] But from the organizational characteristics of the civil affairs department, comparing civil affairs departments acting as guardians and natural persons acting as guardians, the former belongs to an organization (special legal person specified in General Principles of Civil Law ) and does not have the characteristics of always attending to the guardians. Therefore, more supporting mechanisms are needed to facilitate the implementation of the relevant provisions on the civil affairs departments in General Principles of Civil Law; otherwise these articles and clauses will continue to be dead letter. 


\section{References}

[1] Y.L.Deng: China Elderly News, 2017-3-16(001). (In Chinese)

[2] J.L.Zhang and S.Han: China Civil Affairs, (2016)No.21, p. 26. (In Chinese)

[3] S.D.Liu, Judicial Reform-A Calm Reflection On Hot Issues(People's Court Press, 2014).(In Chinese)

[4] J.Xu and Y.X.Dai: Legality Vision, (2016)No.2-1, p.23. (In Chinese)

[5] [US] Reinier Kraakman, Henry B. Hansmann, etc.: The Anatomy of Corporate Law: A Comparative and Functional Approach (Second Edition), translated by P.X. Luo (Law Press, China 2012). (In Chinese)

[6] H.Zhang,: Legal Daily, 2016-4-13(008). (In Chinese)

[7] [US]Ezra F.Vogel: Deng Xiaoping and the Transformation of China, translated by K.L.Feng(Joint Publishing, Chian 2013). (In Chinese)

[8] K.Y.Qi: Journal of China Youth College for Political Sciences, (2017)No.2, p.111. (In Chinese)

[9] Q.Zhao and Q.Li: Juvenile Crime, (2015)No.5, p.71. (In Chinese)

[10]Z.Q.Yin: Journal of East China University of Political Science and Law, (2016)5, p.26. (In Chinese) 